that of surface rock $(3 \cdot 3)$, then the radius of the sphere would be about $\mathbf{2} \cdot \mathbf{7 4}$ miles. Relevant factors, such as the atmospheric resistance and the control of direction, have been neglected. If they were taken into account, the initial mass would be still greater. On these calculations the rocket ship would be more than five miles in diameter, and would be as massive as Mount Everest.

\section{Mammals and Man}

WrTH the view of adding definiteness to the rather vague popular ideas of the class of mammals, the Zoology Department of the National Museum of Wales has set up a temporary series of exhibits for which a descriptive pamphlet, "Mammals and Man", has been written by the keeper of the Department, Colin Matheson (pp. 22. 3d.). The exhibits show representatives of the main groups of mammals, and indicate some of the ways in which mammals con. tribute to the welfare of humanity. Thus it is pointed out that of 3,500 known species of mammals, only about twenty have been thoroughly domesticated, and some of the breeds of the most familiar animals are illustrated among the exhibits. The economic products of the group are represented by wools of various kinds, by furs, particularly dressed furs made from rabbit skins, leather, many products of bones, food materials and so on. The arrangement follows the economic zoology which was a popular diversion of last century, but we miss references to modern developments such as the varied and most important uses of whale oil, the increasing resort to mammal products in biological therapy, and the importance assumed by mammals as reservoirs of disease organisms of man or domestic stock, as in the case of cattle disease in Africa, or as the carriers and communicators of disease, as in the case of the vampire bat. This exhibition, and all such special exhibitions, will do much to keep alive general interest in museum collections, which are always in danger of becoming static and unenterprising.

\section{Mounting Museum Specimens in Plastic}

ONE of the great handicaps in making attractive to the ordinary museum visitor specimens of the smaller organisms has been the need for mounting such in formaldehyde, alcohol, or other fluid, which almost invariably bleaches colour and makes necessary awkward methods of attachment. To a considerable extent that difficulty has been overcome by the use of an acrylic resin, 'Plexiglasis', the product of experiments conducted by Dr. Otto Rohm, of Philadelphia. Dr. Charles E. Sands, of the Bureau of Agricultural Chemistry and Engineering, has developed a method of embedding specimens in blocks of this material so that they resemble fossils preserved in amber, except that 'Plexiglass' is colourless and crystal-clear, clearer it is said than the finest glass, and will retain its transparency permanently. Specimens before embedding must be dehydrated in air or with alcohol or dioxan, and the setting is done in vacuum to prevent the inclusion of air-bubbles while the mountant is changing from semi-fluid to the solid state. A collection of miscellaneous specimens mounted in this way was on view at the New York World's Fair, and is permanently shown in the Franklin Institute in Philadelphia.

\section{Fertility Rules in Fruit Planting}

THE John Innes Horticultural Institution has produced a very useful leaflet (No. 4) with the above title, which sets out clearly the rulès for interplanting fruit trees to ensure effective pollination. Based on many years of research to test the success of crosses between varieties of cherries, plums, pears and apples, this leaflet will be an invaluable guide to growers in the planning of new orchards and in the improvement in fertility of existing trees. It is estimated that the value of the total fruit crop of Great Britain could be increased 10-20 per cent by correct interplanting. In some existing orchards containing large blocks of trees of a single variety, much could be done to increase the crop by top. grafting a proportion of the trees with suitable pollinators. Brief reference is made in the leaflet to the causes of unfruitfulness, and exhaustive lists are provided to show which varieties are self-compatible and which varieties will ensure effective crosspollination. Attention is directed to the reduced population of wild bees in many orchard districts and the necessity for keeping hive-bees in correctly interplanted orchards.

\section{Feeding Value of Silage}

Farmers must be able to judge the feeding value of their silage, and to meet this need the Ministry of Agriculture has issued Bulletin No. 50 in the "Grow. more" series. High-quality silage is a cake substitute and can only be obtained from the right crop, cut at the right time and properly ensiled. The colour, smell, texture and dry-matter content of material in this category are described, and recommendations given as to the rate at which it should be fed. If any of the requisite conditions is not fulfilled, the silage can only be used to réplace hay, roots, or oat straw. The value of such material varies considerably according to the type of crop from which it is made, or to the conditions during ensiling, but suggestions are given as to the rationing of several of the lowprotein silages. For the less experienced farmer, a useful table is included, in which the common faults in silage, their cause and the appropriate remedy are described, and if still further information is desired, application can be made to the county agricultural organiżer.

\section{A New Pavlov Manuscript}

Mr. M. KRUTIKov, who is working at the archives of the Academy of Sciences of the U.S.S.R., has discovered the manuscript of a hitherto unknown work by the Russian physiologist, the late Prof. I. P. Pavlov. The work, which had been submitted for a competition for a prize of the Academy, is entitled "The Centrifugal Nerves of the Heart", and it is dated 1885 ; it consists of 19 pages. It seems that when the manuscript reached the Academy 
it was handed for report to I. Tarkhanov, who, after some time, presented a long scientific review of the work. However, he failed to come to any definite conclusions about it, because of the absolute newness of the subject and the absence of any literature on it. It is hoped to include the new paper in the complete edition of Pavlov's works which the Academy proposes publishing.

\section{The Linnean Society of London}

GENERAL meetings of the Linnean Society of London are to be resumed at 3 p.m. on the following Thursdays: March 6, April 3, and May 1. On March 6, several papers will be read. The centenary of the Royal Botanic Gardens, Kew, as a Government institution occurs on April 1, and at the meeting on April 3, Sir Arthur W. Hill, director of the Royal Gardens, will give some account of the work of Kew during the past hundred years. At the meeting on May 1 , the Society will keep the tercentenary of the birth of Nehemiah Grew, when Dr. Agnes Arber will give an account of him, and of Marcellus Malpighi. The anniversary meeting will be held on May 24, when the president will address the Society. The council is to consider the possibility of prolonging the session into June and July.

\section{Announcements}

OwnNa to the generosity of the Rockefeller Foundation, which has provided a grant for the purpose, the Royal Society is in a position to give some assistance to scientific societies and associations which, as a result of war conditions, are experiencing financial difficulties in the publication of scientific journals.

AMONG the bequests in the will of the late Sir Robert Hadfield, who died on September 30 last, are the following : gold and other medals, diplomas and certificates to the University of Sheffield for any library or museum in connexion with the Faculty of Metallurgy, and failing acceptance, to the Science Museum, South Kensington; his collection of alloy specimens forming the record of his various papers to scientific and technical societies to the Science

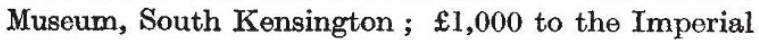
Cancer Research Fund; $£ 1,000$ to the Royal Society for general research work.

Dr. J. BuRTr Davy, late University demonstrato $r$ in forestry in the University of Oxford, who died on August 20, bequeathed a bond for $£ 7,000$, secured on property in the Transvaal, or any of the capital paid, to the Chancellor, masters, and scholars of the University of Oxford, to found a scholarship, "The Burtt-Davy Research Scholarship", for research work in taxonomic botany and/or tropical plant ecology.

THE University of Liverpool is to receive a sum of $£ 2,500$, under the will of Mrs. Mary Harmood Hamilton, to endow a scholarship or scholarships in the Faculty of Engineering.

SrR ANDREw Davidson, county medical officer for the North Riding of Yorkshire, has been appointed to succeed Prof. J. Mackintosh as chief medical officer of the Scottish Department of Health.
Mr. Hector Leak has been appointed president of the Royal Statistical Society, to hold office until the next annual general meeting, in succession to the late Mr. Henry W. Macrosty (see p. 230 of this issue).

Mr. George Grant, registrar of University College, Southampton, since 1923, has been appointed registrar of the University of Birmingham to succeed the late Mr. D. J. Cameron. The status and stipend of registrar have been raised to equality with those of full-time professors.

THE journal Microentomology, issued from the Natural History Museum of Stanford University (California), is now in its fifth volume. Among recent issues that have come to hand are contributions by Dr. G. F. Ferris and others on the detailed external morphology of selected types of the various orders of insects. These accounts are very clearly illustrated by well-executed figures that are intended to meet deficiencies in this respect in many existing publications. The journal, it may be added, is obtainable from the Director of the Museum, and individual parts are obtainable separately at a low price.

Durrng the committee stage in the House of Commons of the War Damage Bill, Sir William Jowitt said, in reply to an amendment put forward by Mr. K. W. M. Pickthorn, one of the representatives of the University of Cambridge, that universities must be regarded, for the purpose of the Bill, as carrying on business. That being so, they would not be exempt from compulsory insurance, but he added that the Government would use its powers under the clause to exempt from the obligation to insure certain classes of the non-essential equipment of universities. He expressed the hope that the Government would receive assistance from the universities and their representatives in formulating a workable scheme.

A cataloque of books relating to Egypt recently issued by Mr. George Salby, oriental bookseller, of 65 Great Russell Street, London, W $` .1$, has a special association interest for Egyptologists and students of the archrology of the Middle East. It includes the libraries of two well-known archæologists. First that of J. L. Starkey, excavator of Lachish, whose assassination by an Arab brought to a premature close one of the most illuminating of recent archæological excavations in Palestine; and secondly, that of Alan W. Shorter, assistant keeper of the Department of Egyptian and Assyrian Antiquities in the British Museum, whose early death cut short a career of much promise. In addition to books which might be termed the tools of a working archiologist, the catalogue includes a number of rarities, among them Prisse d'Avennes "L'Art Arabe", text with three volumes of 200 plates, Rosellini's "Monuments of Egypt and Nubia", and Arthur Upham Pope and Phyllis Ackerman's "A Survey of Persian Art from Prehistoric Times to the Present", the last-named a monumental and scholarly production.

Erratum. In the letter "Rheology of Plastic Materials" in NATURE of February 8, p. 176, for the formula " $\psi=S \sigma^{4} \ell^{k}$ " $\operatorname{read} " \psi=S \sigma^{-1} t^{k}$ ". 